\title{
Economic Growth of Nepal and Its Neighboring Countries
}

\author{
Sovit Lal Bajracharya, Ph.D.*
}

\begin{abstract}
Economic growth and poverty are interrelated. Generally, economic development is believed to reduce poverty. In Nepal, over the last fifteen years, poverty has remarkably come down in spite of lower economic growth meaning that reducing poverty would be much easier if economic growth rate could be increased. Higher economic growth can never be attained unless production and productivity rise. Regarding economic growth of South Asian Countries, Afghanistan accorded first place followed by 10.2 percent, Bhutan second 9.7 percent, China third 7.8 percent. Nepal Sixth 4.6 percent and Maldives occupies last followed by 3.5 percent for the year 2012.
\end{abstract}

Key words: Economic growth, poverty, productivity increment, capital accumulation, Nepal

\section{INTRODUCTION}

Increment of gross domestic product (GDP) of the country perpetually sounds as economic growth. Low economic growth is a core obstacle of economic development. So these two variables are concomitant with one another. The term economic development is used interchangeably with such terms as economic growth, economic welfare, economic progress and secular change. Economic growth is the steady process by which the productive capacity of the economy is increased over time to bring about rising levels of national output and income whereas development is the process of improving the quality of all human lives (Todaro \& Smith, 2003).

Economic growth is measurable and objective. It prescribes expansion in the labor force, in capital, in the volume of trade and consumption. And economic development can be used to describe the underlying determinants of economic growth such as changes in techniques of production, social attitudes and institutions. Such changes may produce economic growth. It has been emphasized that capital accumulation, growth in population and hence labour force, and technical progress are the three components of growth (Todaro \& Smith, 2003). Rodrik (2007, p. 2) notes, "Historically nothing has worked better than economic growth in enabling societies to improve the life chances of their members, including those at the very bottom". So the study of economic growth assumes importance.

\footnotetext{
* Dr. Bajracharya is Associate Professor of Economics at Patan Multiple Campus, Tribhuvan University
} 


\section{LITERATURE REVIEW}

Kindleberger and Herrick (1977) describe that the differences between growth models and development models can be inferred from the differences in the processes of growth and development themselves. Variegated composition of the economy, the differences in sectored responses and the reactions of individuals within a setting of poverty are neglected or ignored by growth models, but they are at the heart of models of economic development. Rawaski (1979) explains that emphasis placed by China on labor force - intensive methods of raising agricultural output, supported by its rural industry's program and the resulting effects on the regional dispersion of industry provide valuable insight, both for countries that have not opted for this as one of the elements of an employment and growth policy and for others that have or are in the throes of doing so. Even if China's political, social and economic system is radically different, there are many examples of how knowledge of its experience can enrich the understanding of those concerned with employment policy else where.

Colander (1993) states that the US economy exhibited growing or expanding trend. Economists use changes in real gross domestic product (real GDP) - the market value of final goods and services produced in an economy, stated in the prices of given year - as the primary measurement of growth when produce and sell their goods, they earn income, so when an economy is growing, both total output and total income are increasing, Such growth gives most people more this year than they had last year. Since most of us prefer more to less, growth is easy to take. Dornbush et al. (2006) delineates that economic growth is due to growth in inputs, such as labor and capital and to improvements in technology: capital accumulates through saving and investment. The long run level of output per person depends positively on the rate of population grow. The neoclassical growth model suggests that the standard of living in poor countries will eventually converge to the level in wealthy countries.

\section{OBJECTIVES OF THE STUDY}

The basic objectives of this paper are (i) to examine the status of economic growth of Nepal, and (ii) to assess the comparison and relationship between economic growth of Nepal with neighboring countries.

\section{METHODOLOGY AND DATA SOURCE}

Descriptive cum survey method is employed here to analyze relationship between economic growths of Nepal with neighboring countries. The macro data used here are based on secondary source. The data are taken from Economic Survey published by Ministry of Finance, Government of Nepal. The data on international perspectives are taken from IMF's publication. 
So as to show relationships amongst economic variables such as overall and agriculture, industrial and service sectors growth of Nepal, statistical tools like regression analysis, correlation, the coefficient of multiple determinations and the adjusted coefficient of determination have been employed.

\section{Measurement of Economic Growth}

Measuring of economic growth supports to the planner to identify and ascertain strategy to be footed for further steps. One can directly compute the growth rate by using the formula:

$$
\mathrm{GNP}_{\mathrm{t}}=\mathrm{GNP}_{\mathrm{b}}(1+\mathrm{r})^{\mathrm{n}}
$$

Where, $\mathrm{t}$ designates the terminal year, $\mathrm{b}$ the beginning year of the period, $\mathrm{n}$ the number of years in the period and $\mathrm{r}$ the average annual rate to be determined. Taking logarithms on both sides of equation (1) and solving for (1+r) gives

$$
\log (1+\mathrm{r})=\frac{\log \mathrm{GNP}_{\mathrm{t}}-\log \mathrm{GNP}_{\mathrm{b}}}{\mathrm{n}}
$$

The average annual growth rate may be determined from a compound interest table by finding the interest rate required to produce the percentage change in the indicated time period. Nominal/Current price value of GNP should be deflated from interest rate or inflation rate to compute real economic growth.

\section{Determinants of Economic Growth in Developing Countries}

Institutional quality - as measured by bureaucratic efficiency, absence of corruption, protection of property rights and the rule of law - is important for economic growth. So are political stability and civil and economic liabilities. Especially important are protection of property rights, a capable and honest bureaucracy and political stability, particularly if initial conditions are favorable for economic take off. There should be assistance to the poor countries so as to make betterment of institutional performance. Only countries that show progress in institution building should receive assistance, in turn it helps to augment economic growth.

\section{Constraints of Economic Growth in Developing Countries}

Constraints of economic growth can also be resumed as the marrows of developing countries to day. In ability to form human capital is a core obstruction of economic growth. Vicious circle of poverty, imperfection of market, low capital formation, rapid population growth, lack of infrastructure, lack of foreign capital, adverse effects of international forces, backward agriculture, lack of entrepreneurship and management 
talent, socio-cultural obstacles, lack of scientific and technical knowledge are also the problems and constraints of economic growth for developing countries.

\section{ECONOMIC GROWTH OF NEPAL}

Economic and social development activities of Nepal are being carried out with objectives of reducing poverty by achieving broader and sustainable economic growth, bringing desirable change in life style of entire Nepalese by adopting inclusive development progress and laying foundation to transform Nepal in to a prosperous Nepal.

Economic growth and poverty are interrelated. Generally, economic development is believed to reduce poverty. Over the last fifteen years, poverty has remarkably come down in spite of lower economic growth meaning that reducing poverty would be much easier if economic growth rate could be increased. Higher economic growth can never be attained unless production and productivity rise. For current fiscal year, it is estimated to grow economic growth by 3.56 percent. A number of factors like ever extending political instability, problems in industrial environment, low private sector investment, energy crisis, lower credit expansion of banks have restricted the growth of industrial production resulted in sluggish economic activities of the nonagriculture sector, there by restricting this sector growth to 4.98 percent. Growth rate of agriculture also stood at 1.26 percent with decline in production of food grains due to absence of follows monsoon and timely monsoon rainfall and insufficient rainfall in the winter. The status of sectorwise economic growth of Nepal is shown in Table 1.

Table 1: Economic Growth of Nepal in the Past Decade

\begin{tabular}{lcccc}
\hline & \multicolumn{5}{c}{ Sectors } \\
\cline { 2 - 5 } Fiscal Years & Agriculture & Industry & Service & Total \\
\hline $2003 / 04$ & 4.7 & 1.5 & 6.8 & 4.4 \\
$2004 / 05$ & 3.5 & 2.9 & 3.3 & 3.2 \\
$2005 / 06$ & 1.9 & 4.4 & 5.6 & 3.7 \\
$2006 / 07$ & 1 & 4 & 4.5 & 2.8 \\
$2007 / 08$ & 5.8 & 1.6 & 7.3 & 5.8 \\
$2008 / 09$ & 3 & -0.6 & 6 & 3.9 \\
$2009 / 10$ & 2 & 4 & 5.8 & 4.3 \\
$2010 / 11$ & 4.5 & 4.4 & 3.4 & 3.8 \\
$2011 / 12$ & 5 & 3 & 4.5 & 4.5 \\
$2012 / 13$ & 1.3 & 1.5 & 6 & 3.6 \\
Average & 3.3 & 2.7 & 5.3 & 4 \\
\hline
\end{tabular}

Source: Ministry of Finance, GON (2013). 
Table 1 depicts that the covered decade was not encouraging for Nepal in terms of economic growth. Except for achieving 5.8 percent economic growth in F/Y 2007/08, growth rate in other years remained limited either to 4 percent or close to it. In fiscal year 2006/07, growth rate stagnated to 2.8 percent. As such the country could achieve the average economic growth rate of 4 percent in the last ten years. During this period, sectorwise growth was also not encouraging. Average growth rates of agriculture, industry and services sectors also stood at 3 percent, 207 percent and 5.3 percent respectively. Table 2 presents the comparative status of Nepal's economic growth with SAARC member countries and china.

Table 2: Economic Growth Nepal and Its of Neighboring Countries

\begin{tabular}{lccccccccc}
\hline Countries & 2004 & 2005 & 2006 & 2007 & 2008 & 2009 & 2010 & 2011 & 2012 \\
\hline Afghanistan & 8 & 14 & 8 & 14.2 & 3.4 & 22.5 & 8.4 & 7 & 10.2 \\
Bangaladesh & 6.1 & 6.3 & 6.7 & 6.3 & 6 & 5.4 & 6.4 & 6.5 & 6.1 \\
Bhutan & 6.8 & 6.5 & 13.7 & 19.7 & 5 & 6.3 & 11.7 & 8.5 & 9.7 \\
India & 7.8 & 9.2 & 9.2 & 9.4 & 7.3 & 5.7 & 11.2 & 7.7 & 4 \\
Maldives & 9.5 & -4.5 & 16.1 & 7.2 & 6.3 & -3.0 & 7.1 & 7 & 3.5 \\
Nepal & 3.8 & 2.7 & 1.9 & 3.3 & 5.3 & 4.7 & 4.8 & 3.9 & 4.6 \\
Pakistan & 7.4 & 8 & 6.2 & 5.6 & 2 & 2.0 & 3.1 & 3 & 3.7 \\
Shrilanka & 5.4 & 6 & 7.5 & 6.8 & 6 & 3.5 & 8 & 8.2 & 6.4 \\
China & 10.1 & 10.4 & 10.7 & 13 & 9.6 & 8.7 & 10.4 & 9.3 & 7.8 \\
\hline
\end{tabular}

Source: IMF (2013).

Table 2 depicts that for the year 2004, China achieved an economic growth of 10.1 percent and took first place in SAARC countries. Maldives, Afghanistan and India had growth rates of 9.5 percent, 8 percent and 7.8 percent placing second, third and fourth places respectively. For the year 2005; Afghanistan had economic growth of 14 percent and took first place in SAARC countries. China, India and Pakistan had growth rates of 10.4 percent, 9.2 percent and 8 percent placing second, third and fourth places respectively. For the year 2006; Maldives had economic growth of 16.1 percent and took first place in SAARC countries. Bhutan, China and India had growth rates of 13.7 percent, 10.7 percent and 9.2 percent placing second, third and fourth positions respectively. Economic growth rate for neighboring countries, India and China, has been encouraging for the year 2007 and 2008. China achieved growth rates of 13 percent and 9.6 respectively in these two consecutive years, while growth rates for India in the same period was 9.4 percent and 7.3 percent respectively. Economic growth rate for the year 2009 is estimated to be relatively lower for both these countries with 8.7 percent for China and 5.7 percent for India. The trend of economic growth in other countries of South Asian Association for Regional Cooperation (SAARC) has been 
mixed for those years. However decline is observed in the growth rate in majority of these countries in 2009 as compared to 2008. Of the South Asian counties, Afghanistan, Bhutan, Nepal and Pakistan have increased economic growth rate in 2012.India and Bhutan that attained double digit economic growth in 2010 saw decline in their growth rates. Since economic growth of Europe and United States of America directly affects the economies of South Asian Countries, economic growth of this region has declined by the change in growth rates of those countries. Like wise, China, the close neighbor of South Asian countries, that was able to attain double digit economic growth in 2010, saw decline in its economic growth in 2011.

So as to know the actual economic growth rate of neighboring countries of Nepal, inflationary rate should be adjusted. The inflationary trend of neighboring countries of Nepal is given in Table 3.

Table 3: Inflationary Trend of Neighboring Countries of Nepal

\begin{tabular}{lllllll}
\hline & \multicolumn{3}{c}{ Years } & \multicolumn{3}{c}{ Projection } \\
\cline { 2 - 7 } Country & 2010 & 2011 & 2012 & 2013 & 2014 & 2018 \\
\hline Afghanistan & 7.1 & 10.4 & 4.4 & 6.1 & 5.8 & 5.0 \\
Bangladesh & 8.1 & 10.7 & 8.7 & 6.5 & 6.2 & 5.5 \\
Bhutan & 7.0 & 8.9 & 9.7 & 10.2 & 9.1 & 6.0 \\
India & 12.0 & 8.9 & 9.3 & 10.8 & 10.7 & 6.7 \\
Maldives & 6.1 & 11.3 & 10.9 & 5.8 & 5.1 & 4.4 \\
Nepal & 9.5 & 9.6 & 8.3 & 9.6 & 8.3 & 5.5 \\
Pakistan & 10.1 & 13.7 & 11.0 & 8.2 & 9.5 & 11.8 \\
Srilanka & 6.2 & 6.7 & 7.5 & 7.9 & 7.1 & 5.5 \\
China & 3.3 & 5.4 & 2.6 & 3.0 & 3.0 & 3.0 \\
\hline
\end{tabular}

Source: IMF (2013).

Table 3 reveals that for the years, 2010, 2011, 2012 Pakistan accorded inflationary rates of 10.1 percent, 13.7 percent and 11 percent respectively. It is predicted to grow by 11.8 percent in 2018. For the years 2010, 2011, 2012, India had inflation of 12.0 percent, 9.3 percent and 11 percent respectively. It is predicted to be of 6.7 percent in 2018. China occupies least inflationary pressure for the years 2010, 2011 and 2012 as it is found by 3.3 percent, 5.4 percent, 2.6 percent respectively. It is forecasted to reach by 3.0 percent in 2018. For the years 2010, 2011, 2012, Nepal has price rise of 9.5 percent, 9.6 percent and 8.3 percent respectively. It is estimated to be of 5.5 percent in 2018 . The relationship between agriculture and total economic growth of Nepal or contribution of agriculture to total economic growth is shown in Table 4. 
Table 4: Contribution of Agriculture to Total Economic Growth of Nepal

\begin{tabular}{lcc} 
Fiscal Year & Agriculture & Total Economic Growth \\
\hline $2003 / 04$ & 4.7 & 4.4 \\
$2004 / 05$ & 3.5 & 3.2 \\
$2005 / 06$ & 1.9 & 3.7 \\
$2006 / 07$ & 1 & 2.8 \\
$2007 / 08$ & 5.8 & 5.8 \\
$2008 / 09$ & 3 & 3.9 \\
$2009 / 10$ & 2 & 4.3 \\
$2010 / 11$ & 4.5 & 3.8 \\
$2011 / 12$ & 5 & 4.5 \\
$2012 / 13$ & 1.3 & 3.6 \\
\hline
\end{tabular}

Source: Author's computation from the Economic Survey (2013) Data released by Ministry of Finance, Government of Nepal.

Table 4 shows contribution of agriculture to total economic growth of Nepal for different years. Here, contribution of agriculture sector's growth(x) is regarded as independent variable and total economic growth(y) as dependent variable. In order to show the relationship between contribution of agriculture and total economic growth we fit a simple regression model of the form

$$
\mathrm{y}=\mathrm{a}+\mathrm{bx}
$$

From this equation we can compute the value of the regression coefficient ' $b$ ' using the formula

$$
\mathrm{b}_{\mathrm{xy}}=\frac{\sum \mathrm{xy}}{\sum \mathrm{y}^{2}}
$$

We can find the value of regression coefficient by calculating $\sum x y$ and $\sum y 2$ and dividing the former by later.

The computation of the regression coefficient and other statistics were found as follow:

$\mathrm{b}_{\mathrm{xy}}=0.729, \mathrm{R}$ - square $=0.532$, Adjusted R- square $=0.474$, standard error of the estimate $=0.5983$ and $F=9.095$. Thus result evidences the significant contribution of agriculture sector in total economic growth of Nepal. 
The comparative status of growth of agriculture sector to the overall economic growth of Nepal is presented in Figure 1.

Figure 1: Contribution of Agriculture to the Total Economic Growth of Nepal

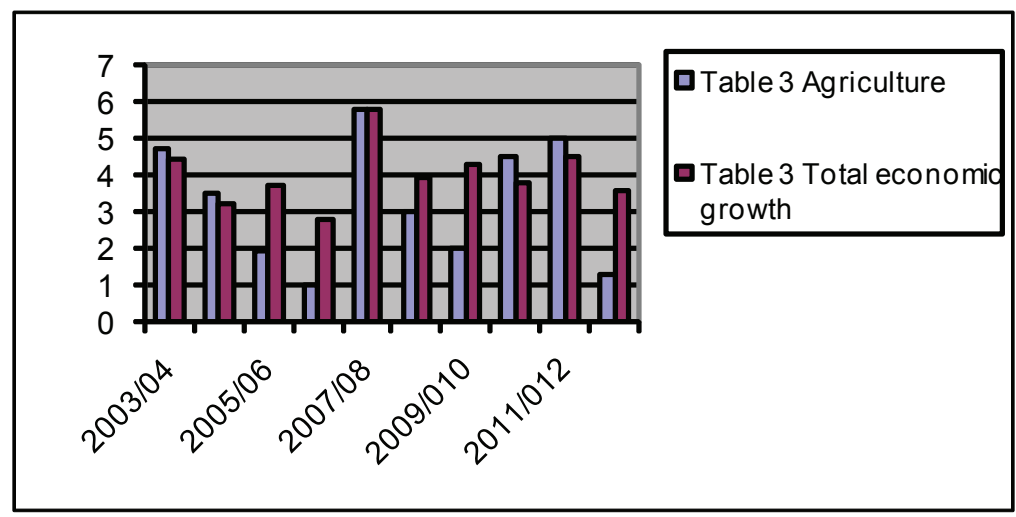

The relationship between Industry and total economic growth of Nepal, that is, the contribution of the industrial sector to total economic growth is shown in Table 5.

Table 5: Contribution of Industry to Total Economic Growth

\begin{tabular}{lcc}
\hline Fiscal Year & Industry & Total \\
\hline $2003 / 04$ & 1.5 & 4.4 \\
$2004 / 05$ & 2.9 & 3.2 \\
$2005 / 06$ & 4.4 & 3.7 \\
$2006 / 07$ & 4 & 2.8 \\
$2007 / 08$ & 1.6 & 5.8 \\
$2008 / 09$ & -0.6 & 3.9 \\
$2009 / 10$ & 4 & 4.3 \\
$2010 / 11$ & 4.4 & 3.8 \\
$2011 / 12$ & 3 & 4.5 \\
$2012 / 13$ & 1.5 & 3.6 \\
\hline
\end{tabular}

Source: Author's computation from the Economic Survey Data released by Ministry of Finance, Government of Nepal.

Table 5 shows contribution of industry to total economic growth for different years. Here, industrial contribution is regarded as independent variable and total economic growth as dependent variable. In order to show the relationship between contribution 
of industry $\left(\mathrm{x}_{1}\right)$ and total economic growth(y) a regression of the form (5) was fitted and estimated

$$
\mathrm{y}=\mathrm{a}_{1}+\mathrm{b}_{1} \mathrm{x}_{1}
$$

From this equation we can compute the value of the regression coefficient ' $b_{1}$ ' using the formula

$$
\mathrm{b}_{\mathrm{x}_{\mathrm{y}} \mathrm{y}}=\frac{\sum \mathrm{x}_{1} \mathrm{y}}{\sum \mathrm{y}^{2}}
$$

As mentioned in the case of agriculture sector's contribution to total economic growth, we can find the value of regression coefficient ' $b_{1}$ ' by calculating $\sum \mathrm{x}_{1} \mathrm{y}$ and $\sum \mathrm{y}^{2}$ and dividing the former by the later. Here $b_{1_{1} \mathrm{y}}=0.302$, R-square $=0.532$, Adjusted $\mathrm{R}$ - square $=0.474$, standard error of the estimate $=0.5983$ and $\mathrm{F}=0.803$. As the value of F-statistic is very low it appears that there is insignificant contribution of industrial sector in total economic growth of Nepal.

The comparative status of growth of industrial sector to the overall economic growth of Nepal is presented in Figure 2.

\section{Figure 2: Contribution of Industry to Total Economic Growth}

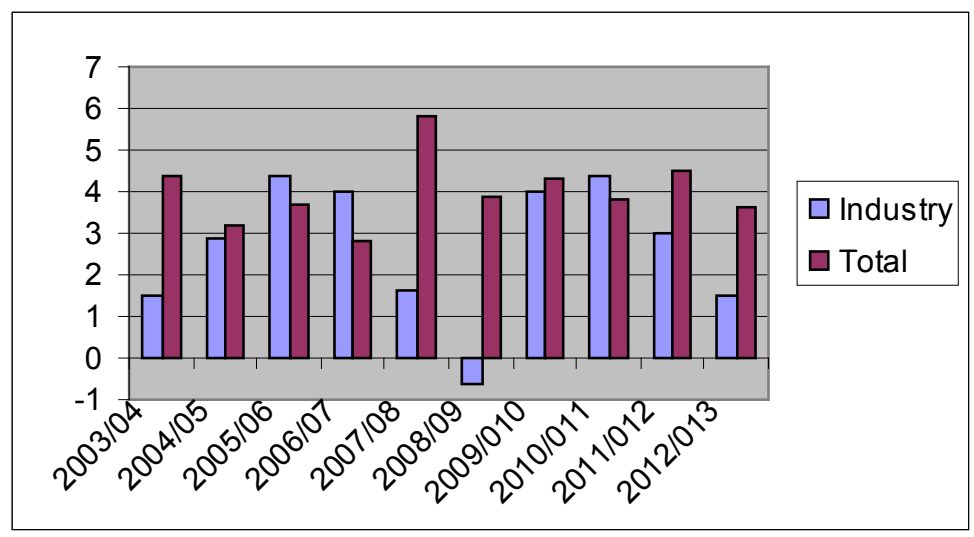

The relationship between service and total economic growth of Nepal, that is, the contribution of service sector to total economic growth of Nepal is in Table 6. 
Table 6: Contribution of Service Industry to Total Economic Growth

\begin{tabular}{lcc}
\hline Fiscal Year & Service & Total \\
\hline $2003 / 04$ & 6.8 & 4.4 \\
$2004 / 05$ & 3.3 & 3.2 \\
$2005 / 06$ & 5.6 & 3.7 \\
$2006 / 07$ & 4.5 & 2.8 \\
$2007 / 08$ & 7.3 & 5.8 \\
$2008 / 09$ & 6 & 3.9 \\
$2009 / 10$ & 5.8 & 4.3 \\
$2010 / 11$ & 3.4 & 3.8 \\
$2011 / 12$ & 4.5 & 4.5 \\
$2012 / 13$ & 1.56 & 3.6 \\
\hline
\end{tabular}

Source: Author's computation from the Economic Survey (2013) Data released by Ministry of Finance, Government of Nepal.

Table 6 shows contribution of service to total economic growth $\left(\mathrm{x}_{2}\right)$ for different years. Here, service sector $\left(\mathrm{x}_{2}\right)$ contribution is regarded as independent variable and total economic growth(y) as dependent variable. In order to show the contribution of service $\left(\mathrm{x}_{2}\right)$ and total economic growth(y) a regression of the form (7) was used and estimated

$$
\mathrm{y}=\mathrm{a}_{2}+\mathrm{b}_{2} \mathrm{x}_{2}
$$

From this equation we can compute the value of the regression coefficient ' $b_{2}{ }^{\prime}$ using the formula

$$
\mathrm{b}_{2 \mathrm{x}_{2} \mathrm{y}}=\frac{\sum \mathrm{x}_{2} \mathrm{y}}{\sum \mathrm{y}^{2}}
$$

As mentioned in earlier cases we can find the value of regression coefficient ' $b_{2}$ ' by calculating $\sum \mathrm{x}_{2} \mathrm{y}$ and $\sum \mathrm{y}^{2}$ and dividing the former by the later. In the computation the regression coefficient and other statistics were found as: $b_{2 x_{2} y}=0.643$, R-square $=0.413$, Adjusted R-square $=0.340$, standard error of the estimate $=0.6701$ and $\mathrm{F}=$ 0.803 . As the value of the computed $F$ statistic indicating the overall goodness of fit of the model is very low, contribution of the service sector in the total economic growth is not encouraging.

The comparative status of the service sector growth and the total economic growth is demonstrated in Figure 3. 
Figure 3: Contribution of Service to Total Economic Growth

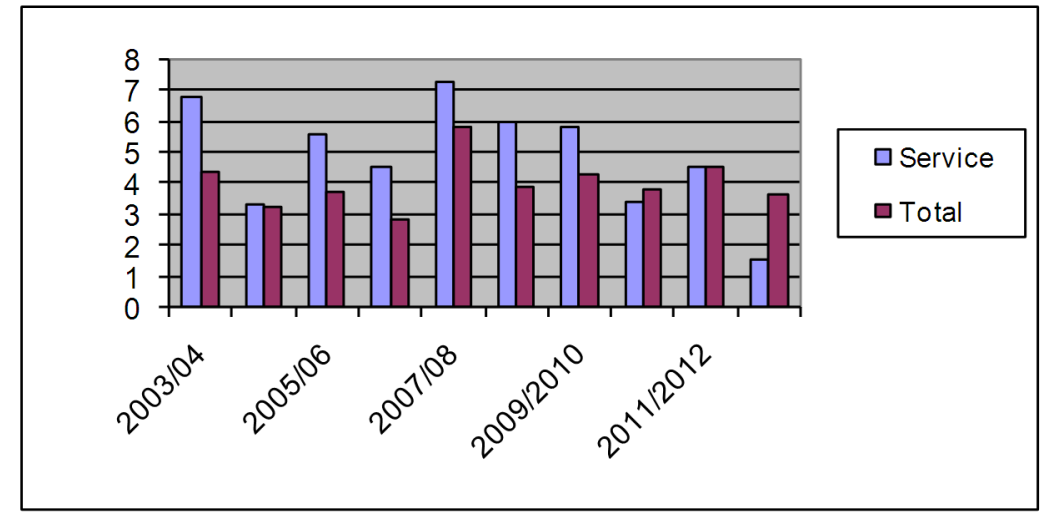

Over the period covered in this study the contribution of service sector remained positive but unsustained.

\section{CONCLUSION}

For the economic growth status analysed in this study a number of factors like ever extending political instability, problems in industrial environment, low private sector investment, energy crisis, lower credit expansion of banks have restricted the growth of industrial production resulted in sluggish economic activities of the non-agriculture sector, there by restricting this sector's growth. Growth rate of agriculture also stood at 1.26 percent with decline in production of food grains due to absence of follows manner. Untimely monsoon rainfall and insufficient rainfall in the winter affected agriculture sector's growth. Preceding decade was not encouraging for Nepal in terms of economic growth. Except for achieving 5.8 percent economic growth in F/Y 2007/08, growth rate in other years remained limited either to 4 percent or close to it.

For the year 2004, China had economic growth of 10.1 percent and took first place in SAARC countries. Maldives, Afghanistan and India had growth rates of 9.5 percent, 8 percent and 7.8 percent placing second, third and fourth respectively. Of the South Asian counties, Afghanistan, Bhutan, Nepal and Pakistan increased economic growth rate in 2012.India and Bhutan that attained double digit economic growth in 2010 saw decline in their growth rates. Since economic growth of Europe and United States of America directly affects the economies of South Asian Countries, economic growth of this region has declined by the change in growth rates of those countries. Like wise, China, the close neighbor of South Asian countries, that was able to attain double digit economic growth in 2010, saw decline in its economic growth in 2011. 


\section{References}

Colander, D.C.(1993).Macroeconomics. Middlebury College, McGraw Hill, Irwin.

Dornbush, R. et al.(2006). Macroeconomics. New Delhi: Tata McGraw Hill Publishing Company New Delhi.

Government of Nepal, Ministry of Finance. (2013). Economic survey. Kathmandu:Author.

IMF.(2013). World economic outlook. Washington, D.C.: Author

Kindleberger, C.P., \& Herrick, B. (1977). Economic development. McGraw-Hill Kogakusha, Ltd, International Students Union.

Rawski, T.G. (1979). Economic growth and employment in China. World Development, 7, 767-782.

Rodrik, D. (2007). One economics, many recipes: Globalization, institutions, and economic growth. Princeton, NJ: Princeton University Press.

Todaro, M.P. \& Smith, S.C. (2003).Economic development ( (th $^{\text {th }}$ ed.). Delhi: Pearson Education 